\title{
CONFESSING GUILT IN THE CONTEXT OF CLIMATE CHANGE: SOME SOUTH AFRICAN PERSPECTIVES ${ }^{1}$
}

\author{
Ernst M Conradie \\ Religion and Theology \\ University of the Western Cape
}

\begin{abstract}
This contribution explores the significance but also the immense complexities of Christian discourse on confessing guilt within the context of climate change. It draws especially on South African discourse on confessing guilt in the context of apartheid. The argument of the essay is twofold: Christians with an enduring large carbon footprint may wish to confess their guilt in this regard, but typically find it difficult to live from God's liberating forgiveness and are therefore prone to rather desperate efforts to save the world themselves. By contrast, Christians with a small carbon footprint may opt for alternative understanding of salvation, namely in terms of redemption from the looming threat of climate change.
\end{abstract}

Key Words: Climate Change, Confession, Guilt, Forgiveness, South Africa

Only when the rich confess the ecological harms or 'ecological debts', with which they burden the poor and other species through the deregulated global economy will it be possible for the poor to gain justice and for climate debts to be justly redeemed. ${ }^{2}$

\section{Introduction: The Need for Moral Imagination}

From within the Southern African context, discourse on climate change, in my opinion, has to be understood in the light of the following four brief observations:

1) There is widespread consensus, at least in ecumenical literature on climate change, that this is an issue of justice since the first victims of climate change will be those who are already poor, marginalised and vulnerable. ${ }^{3}$ This certainly also applies to impoverished rural communities in southern Africa. It is widely predicted that rainfall patterns will change in the region and that this will lead to crop failure, to desertification in some

1 A German translation of this article has been published as "Schuld eingestehen im Kontext des Klimawandels”, Salzburger Theologische Zeitschrift 12:1, 48-74. It has not been published in English before. For a popularised and condensed version of aspects of the same argument, see also chapter 6 of my The church and climate change: Signs of the Times Series Volume 1 (Pietermaritzburg: Cluster Publications, 2008).

2 Michael Northcott, A moral climate: The ethics of global warming (Maryknoll: Orbis Books, 2007), p. 43.

3 This is the angle taken by the World Council of Churches in its many statements on climate change. It argues that "human-induced climate change is being precipitated primarily by the high consumption lifestyles of the richer industrialised nations and wealthy elites throughout the world while the consequences will be experienced disproportionately by impoverished nations, low-lying island states, and future generations. Climate change is thus a matter of international and intergenerational justice.” See Climate change (Geneva: WCC 2005), p. 72. 
areas, to water scarcity and to a spread of diseases such as malaria. Increasingly the poor may become environmental refugees, live in highly polluted urban areas and will lack food, drinking water and adequate sanitation and health services. In the foreword to Africa - Up in smoke? Archbishop Desmond Tutu captures the implications for Africa:

The world's wealthiest countries have emitted more than their fair share of greenhouse gases. Resultant floods, droughts and other climate change impacts continue to fall disproportionately on the world's poorest people and countries, many of which are in Africa ... [There is also a need to recognize] the strength and creativity of African people in times of stress. What is needed most now is that Africans are supported in their efforts to build on those strengths. ${ }^{4}$

2) At the same time, carbon emissions in South Africa are very high. According to the latest Human Development index, South Africa contributed 436.8 million tons of $\mathrm{CO}_{2}$ emissions in 2004. This is $12^{\text {th }}$ on the list of $\mathrm{CO}_{2}$ emissions by country. This translates into 9.8 tons of $\mathrm{CO}_{2}$ per person, up from 9.1 tons in 1990 and compares with 20.6 tons per person in the USA and 0.2 tons in Zambia. The share of the income and expenditure of the most affluent $10 \%$ of South Africa's population (47.5 million people) is $44.7 \%$. On this basis one may calculate their annual $\mathrm{CO}_{2}$ emissions to be in the region of 41.1 tons per person. This has to be compared with the global average of 4.5 tons and sustainable levels of approximately 2 tons per person.

3) The availability of large supplies of readily available coal has long been regarded as one of the assets of the South African economy. Mr Alec Erwin, the long-standing ANC Minister of Public Enterprise (formerly Trade and Industry), has repeatedly argued that this constitutes South Africa's niche in the highly competitive globalised economy. With the decline of the share of mining in the economy this is our ticket to prosperity. The government therefore seeks to lure large business corporations to invest in South Africa on the basis of the pledge of cheap electricity.

4) After 1994 there has been a very rapid transformation of the demographic profile of the affluent in South Africa with more and more people of colour joining the consumer class. However, the poorest $40 \%$ of the population are left further and further behind. Many have obtained access to housing and electricity but, crucially, not to employment or to education in good public schools. The stark economic inequalities have spurred on not only pervasive levels of crime and corruption but also a rampant form of consumerism, if not naked greed, not only amongst the wealthy elite but also amongst the lower middle class and the poor. In this context the prosperity gospel thrives. Consumerism was the topic of the Nelson Mandela Memorial lecture, delivered by President Thabo Mbeki on July 29, 2006. He noted:

Thus, everyday, ... the demons embedded in our society, ... advise, with rhythmic and hypnotic regularity - get rich! get rich! get rich! And thus has it come about that many of us accept that our common natural instinct to escape from poverty is but the other side of the same coin on whose reverse side are written the words - at all costs, get rich! ... In these circumstances, the meaning of freedom has come to be defined not by the seemingly ethereal and therefore intangible gift of liberty, but by the designer labels on the clothes we wear, the cars we drive, the spaciousness of our houses and our yards, their geographic location, the company we keep, and what we do as part of that company.

4 See Africa - Up in smoke? (2005). 
In my view the tension between these observations indicates that climate change has to be addressed in the context of stark economic inequalities. As often in the past the South African situation here serves again as a parable for global discourse.

The challenge that this prompts is perhaps best understood as one of moral imagination. What will we do when oil resources become depleted? Can we imagine a world without oil? The emergence of the industrialised economy was based on a shift from animal power to coal and then to oil. How can the energy basis of the entire industrialised economy be altered within the space of approximately 40 years? Or to put this in other terms: The question is whether "a different world is possible" - as the 2005 World Social Forum in Porto Allegro famously professed. Where can alternatives to industrialised capitalism be found - that will be able to generate sufficient wealth (as adequately as industrialised capitalism), that will be able to distribute such wealth more equitably (as introduced in various forms of socialism that presuppose such generation of wealth) and that will help to redefine our very understanding of what wealth entails (as proposed in the so-called 'new economics' movement)?

The need for such moral imagination has become widely recognised in the context of discourse on climate change. Some argue that the technological solutions are available to curb human-induced climate change. The information is available. There has been no lack of appeals to take the necessary steps. The reports of the Intergovernmental Panel on Climate Change have received maximum media coverage. However, to address climate change will demand far more than what science and new technologies may offer. That is illustrated by the situation that many countries with a well-educated and well-informed population remain reluctant or unable to meet the moderate targets stipulated in the Kyoto protocol. ${ }^{5}$ The underlying problem is clearly not just a lack of information or planning. It is a liberal fallacy to assume that information and education is sufficient for moral action. It is less a problem of know-what or know-how than of know-why and know-wherefore. The question is therefore this: How would it be possible to muster sufficient political will and voter support from all over the world to address climate change? How can the habits, attitudes and consumerist aspirations of the world's 6.7 billion people be re-orientated?

Current initiatives to find answers to these questions are thwarted by at least four factors. Firstly, there is a need to recognise that levels of consumption and the use of energy, also of fossil fuels, are still rising amongst the consumer class alone. Affluence leads to inertia and a voluntary simplification of lifestyles seems to fall outside the desire of the consumer class. Secondly, the global human population is still predicted to rise from the current 6.7 billion to around 9 billion in 2050. Thirdly, the rapid expansion of the economies of China and India can scarcely be halted. Fourthly, the hope and aspiration of the world's poor is to attain the standard of living that they observe amongst the affluent.

The levels of consumption enjoyed by the affluent (in South Africa) therefore raise serious questions of global justice. It can only be sustained at the expense of others - the poor, coming generations and other living organisms. It would simply not be possible for the planet's entire human population to replicate the lifestyle of the affluent centre. The solution cannot be a system of consumer apartheid that upholds affluent binge habits but denies the poor a decent standard of living. The affluent who wreaked environmental havoc so that they might attain a comfortable and healthy lifestyle clearly cannot caution others not to seek a comparable standard of living because that would jeopardise ecological sustainability.

Likewise, even though South Africans are generally well-informed about HIV/Aids such awareness seems to be insufficient to stop the rampant spread of HIV-infection. 


\section{Christian Discourse on Climate Change}

Within this context, the question is what Christianity can contribute to the emergence of the kind of moral vision that is required? What distinct message can Christians bring to the table of international discourse on climate change? How can it do so on its own terms and not merely in lieu of the need for public morality - the place that modern societies since Kant have allowed for religion?

There will be no easy answer to this question, if only because those countries which have a proportionally high per capita emission of greenhouse gases are also those countries where Christianity has historically been influential. Indeed, Christianity has been as much part of the problem as of the solution. This calls for nothing less than an ecological reformation of the Christian tradition. Moreover, Christians with a large carbon footprint face other Christians with a small carbon footprint across the table. While Christianity is associated with the affluent West, at least historically, in (South) Africa most church members are indeed poor and the likely victims of climate change. The problem is that such Christians typically come to the table of international dialogue on climate change without having been reconciled with one another at the Lord's table.

The available Christian responses to climate change have rightly focused on ethical reflection and a concern for justice. ${ }^{6}$ The documents issued by ecumenical organisations are quite similar in style, content and emphasis compared to reports from the Intergovernmental Panel on Climate Change, the Worldwatch Institute, the Nicholas Stern commission or the Climate Action Network. This is appropriate given the need for an ethical convergence $^{7}$ and for Christian participation in global forums where climate change is being addressed through cooperative efforts. Nevertheless, it is somewhat of an indictment on the church that it has merely reiterated what is offered in secular discourse. Christian discourse on climate change is apparently not taking its own message seriously ${ }^{8}$ and has largely failed to make the distinct contribution that it can indeed make.

There is a whole range of symbols which may be retrieved for a Christian response to climate change albeit that they are all rather ambiguous. Here one may merely mention the role of apocalyptic forebodings, a sense of gratitude for the sacred gift of God's good creation, an emphasis on human equality, recognition of God's nourishing providence, the position of the church as an alternative community, a retrieval of virtue ethics, calls for an ethics of stewardship and the message of redemption from threats such as climate change.

In the rest of this essay I will explore the Christian message of redemption in more detail. I recognise that there are several quite different notions of such redemption, symbolised by categories such as victory over the forces of evil, destruction and death (or liberation), reconciliation, moral inspiration and theosis. I will focus on one such a soteriological category, namely the need for reconciliation and the role of confession, guilt and forgiveness in this regard. ${ }^{9}$ The question is whether a Christian confession of guilt may

$6 \quad$ In addition to several newsletters, reports and statements, see especially Accelerated climate change: Sign of peril, Test of faith (1993), Solidarity with victims of climate change (2002), Climate change (2005),

Alternative Globalization Addressing Peoples and Earth (AGAPE): A Background Document. These texts were all produced by the Justice, Peace and Creation Unit of the World Council of Churches and are available from the WCC website, www.wcc-coe.org/wcc/what/jpc/

7 See Wolfgang Huber, Es ist nicht zu spät für eine Antwort auf den Klimawandel: Ein Appell des Ratsvorsitzenden der Evangelischen Kirche in Deutschland. EKD-Texte Heft 89 (30/5/2007.), www.ekd.de

8 See Wolfgang Huber, Kirche in der Zeitenwende: Gesellschaftlicher Wandel und Erneuerung der Kirche (Gütersloh: Bertelsmann Stiftung, 1998).

9 It is impossible to offer a survey here of Christian literature on guilt, the confession of sin, the forgiveness of 
be appropriate here given the stark global inequalities mentioned above. This focus is prompted by the polarisation that characterise discourse on climate change - between East and West, North and South, the consumer class and the poor, (over)-industrialised and socalled 'developing' economies, gated communities and (environmental) refugees, previous and coming generations and between the interests of humankind and otherkind. One may therefore argue that the dangers of climate change can only be addressed on the basis of some form of reconciliation which would facilitate cooperation between people from different continents, cultures and religions.

I will first investigate South African discourse on confessing guilt within the context of the struggle against apartheid, especially in the 1980s. I will then draw from this in order to offer some observations on confessing guilt in the context of climate change.

I realise, of course, that there is much cultural resistance against the language of guilt. ${ }^{10}$ However, as I will argue below, without recognition of the unmistakable guilt that there is, no solution to climate change will be found. What is required here is some discernment of the unfathomable depths of evil. Without that, the deepest roots of the problem cannot be uncovered, any analysis will remain shallow and solutions offered facile. Moreover, Christian discourse on sin and guilt ${ }^{11}$ is misunderstood when it is heard as something sombre and dreary and not as part of the gospel of forgiveness and therefore as something joyous.

\section{The Beneficiaries of Apartheid}

The brief of the Truth and Reconciliation Commission (TRC) in South Africa was to investigate what was described as 'gross' violations of human rights (only). This focus was necessary in order to deal with the most notorious cases and to confine the already huge task of the TRC. This 'extremely narrow focus' should also be understood within the context of the political compromise during the transition period whereby it was agreed that amnesty will be granted to politically motivated acts of violence. This limitation had at least two significant implications.

Firstly, it did not provide those who were on the receiving end of many relatively minor acts of discrimination with an opportunity to tell their story. The system of apartheid is often associated with police brutality and the repression of protest. However, it also legalised and institutionalised a way of classifying people that disrespected their basic

sin and reconciliation. Within the South African context alone there is a wealth of such literature.

10 This cultural critique against the role of guilt consciousness was famously expressed by Nietzsche in Geneaology of Morals (1887) and by Freud in Totem and taboo (1913). See also Wolfhart Pannenberg's essay "Protestant piety and guilt consciousness" in Christliche Spiritualität (Göttingen: Vandenhoeck \& Ruprecht, 1986). The core of this critique is that pastors tend to emphasise the guilt of their followers so that such followers would remain dependant on the forgiveness offered to them in God's name. This leads to bad conscience, an exaggerated guilt consciousness that can become neurotic and psychotic. Pannenberg argues that this critique is indeed valid and that the widespread loss of a guilt consciousness in the Western world is entirely appropriate. Instead, he suggests that the Christian message is precisely one of liberation from sin and death through communion with Christ.

11 The categories of guilt and sin are closely related to one another, especially if guilt is seen as guilt before God. Sin is best understood in terms of the collective condition of humanity before God and should not be reduced to slight mistakes, specific immoral actions, moral shortcomings or habitual failings. That would amount to a superficial, moralistic and legalistic notion of sin. Alternatively, sin may become trivialised, for example in the sense of "sin tax". By contrast, guilt is a legal term that indicates that we are responsible for what we have done. Confessing guilt therefore means taking responsibility for what is wrong and not shifting the blame somewhere else. See John de Gruchy, “Confessing guilt in South Africa today”, in Bongani Finca et al, Confessing guilt in South Africa: The responsibility of churches and individual Christians (Braamfontein: SACC, 1989), p. 36. 
dignity. This happened in numerous ways, through people's body language, the use of derogatory terms, through insults, through the way in which customers were treated and through a lack of opportunities and services. Such victims were denied an opportunity of telling their stories of suffering.

Secondly, it did not address a category of people who were not perpetrators of gross human rights violations, but who were nevertheless beneficiaries of the system. Several analysts have demonstrated that apartheid was a political system that was deliberately aimed at benefiting a certain sector of the population. Such beneficiaries included those who benefited from the system through the legal apparatus of the state in terms of the allocation of job opportunities, education, infrastructure, housing and various health and social services. In a famous speech UCT professor Mahmood Mamdani suggested that reconciliation between the beneficiaries and the victims of apartheid is as important as between perpetrators and victims. He therefore called for a special tax through which the previously advantaged have to pay for the wrongs of the past. ${ }^{12}$

It should also be noted that the beneficiaries of apartheid did not only include those who propagated the system, those who formulated the policies, those who implemented the laws or those who supported the system in one way or another - by voting, by condoning, by not resisting it or by not fighting against it hard enough (according to their own confession). It included everyone who benefited from it indirectly, whether they liked it or not, whether they were aware of it or not, whether they were campaigning against it or not. The beneficiaries included many pious, hard-working and frugal people who may or may not have supported the apartheid policies. This remains one of the unanswered enigmas of apartheid: Why did so many 'good people' support an evil system? Under what conditions is such a selective morality possible?

During the transition period in South Africa from 1990 to 1994 the evils of apartheid were widely denounced. It became difficult to find people who would acknowledge that they ever supported apartheid. Nevertheless, during and beyond this period there emerged ongoing discourse on the notion of corporate guilt, including the guilt of one's ancestors. ${ }^{13}$ This was widely discussed but seldom analysed in Afrikaner circles, partly because the term 'Afrikaner' became increasingly controversial as a form of self-description. Many distanced themselves from the term, probably because they wished to distance themselves from such guilt and responsibility. They could easily enough distance themselves from the gross violations of human rights perpetrated by certain individuals. Being a tacit beneficiary of apartheid was discussed much less in white English-speaking circles where this notion would also be relevant.

In the wider cultural context there is today still very little recognition of the category of being beneficiaries of apartheid. Instead, a recent lyric by the group 'Beeskraal' proclaims: “Ek sal nie langer jammer sê nie!” (I won’t say sorry no more). This cry may be understood as a form of resistance against what is often called a misplaced 'guilt trip' by 'bleedingheart liberals', a masochistic sense of guilt that invariably becomes destructive, perhaps the

12 See Mahmood Mamdani, “Reconciliation without justice”, Southern African Review of Books No. 46 (1996).

13 Gregory Jones (Embodying forgiveness: A theological analysis (Grand Rapids: WB Eerdmans, 1995, p. 62), observes that he is not somehow guilty for the enslavement of Africans by his ancestors in the $17^{\text {th }}$ century. However, he confesses to be "culpable for that history in the sense that the effects of slavery continue to mar my relation with others, making me complicit in the continuing racism of the culture in which I was born. I can either remain complicit in that racism, thereby perpetuating in ways for which I am also culpable; or I can struggle against it, seeking to mitigate its effects through faithful discipleship.” In my view the category of beneficiaries helps to explain and radicalise the ways in which such relationships are marred. 
product of puritan self-castigation. Many wish to distance themselves from any language about guilt and responsibility, albeit that this is hardly possible and futile. ${ }^{14}$ This cry may also be seen as a form of self-assertion that is related to experiences of frustration (missing opportunities for promotion due to affirmative action) or suffering (being brutalised by violent crime or the murder of family members).

Such self-assertion may be appropriate but can also be dangerous given our selective memories. We tend to remember only the suffering that we experienced and not that which we caused. Thus Germans may remember the bombing of their cities but not their support for Nazi policies. Afrikaners may remember suffering at Bloukrans or in the British concentration camps but not the suffering induced by their support for apartheid. The consumer class may sense a need to protect their interests in gated communities while forgetting the sources of economic inequality. Indeed, guilt is far more deceptive and pervasive than we may think.

What makes the matter enormously complex is that such benefits of apartheid, deeply ambiguous as they certainly are, have accrued over a long period of time. To make this more personal: As a tenth-generation Euro-African male my position in society as a university lecturer is not merely a function of my own hard work, my genetic inheritance, the opportunities that my parents provided me (at significant costs, it may be added) or the underestimated long-term value of the piety, missionary commitment and frugal lifestyles of many generations before me. It is also built upon the trade of the Dutch East Indian Company, on slavery, on Dutch and British imperialism, on the wars fought and won in the conquest of land and a history of 350 years of colonialism in South Africa and the many forms of violence that entails. Although both my children were born long after 1994, they remain such beneficiaries. Their cultural background, financial inheritance and opportunities for a good education will hugely outweigh whatever impact affirmative action or black economic empowerment may have on them in years to come. What make such benefits ambiguous are not only the moral dilemmas and the anxieties that this brings, but also the recognition that at least $3 \%$ of my genetic inheritance comes from a number of enslaved women. I am predominantly the child of slave owners but also of slaves.

One may therefore conclude that being (and remaining) a beneficiary of apartheid implies some form of guilt. Such guilt is not directly related to acts of either gross or minor violations of human rights. One may also incur guilt by being a (willing or unwilling) beneficiary or by being a not so innocent bystander.

It should also be noted that the beneficiaries of apartheid were victims of the system too. This is true in the sense that an oppressor typically becomes victimised by his or her own acts of oppression - given the associated sense of guilt, anxiety and fear for retribution. It is also true in the sense that those who recognised the inherent flaws of the system, but were unable to see an alternative, lived under a cloud of social instability. Could this serve as a parable for those in the consumer class responsible for carbon emissions?

14 The best exposition of this futile attempt to distance oneself from such guilt is perhaps found in Antjie Krog's Country of my skull (Johannesburg: Random House, 1998). She movingly reflects on her own feelings of trying to distance herself from those who sought amnesty for gross violations of human rights. She says: "What do I do with this? They are as familiar as my brothers, cousins and school friends. Between us all distance is erased. Was there perhaps never a distance except the one I built up with great effort within myself over the years? ... From the accents I can guess where they buy their clothes, where they go on holiday, what car they drive, what music they listen to. What I have in common with them is a culture - and part of that culture over decades hatched the abominations for which they are responsible. In a sense it is not these men, but a culture that is asking for amnesty" (p. 96). 


\section{Confessing Guilt in South Africa: German Analogies}

In the South African context, divided by decades of apartheid, the role of story-telling is often emphasised as crucial for the recognition of guilt. Guilt cannot be discovered merely through self-examination. It is only through hearing the stories of others that you can discover what you have done and what you have been condoning. This is indeed crucial for the sake of a 'healing of memories'.

In the 1980s when the social and political system of apartheid became more unstable and its flaws apparent, there emerged, at least in some Christian circles, discourse on the notion of confessing guilt in South Africa. There were many questions: Who should confess guilt? Why? Towards what ends? To whom? Where? When?

In an attempt to grapple with these questions several South African theologians investigated similarities and differences with confessing guilt in Germany after World War II. Here the theology of Dietrich Bonhoeffer was especially inspirational. German documents such as the Stuttgart Confession of Guilt of the Synod of the Evangelical Church in October 1945 and the Darmstadt Declaration of 8 August 1947 were studied. What was striking from these German confessions, controversial as they were, is that those who confessed their guilt were people who fought against Nazism and suffered greatly in the process. They confessed their guilt, in the famous words of the Stuttgart declaration "for not witnessing more courageously, for not praying more faithfully, for not believing more joyously and for not loving more ardently". ${ }^{15}$ They were not judging the nation, but expressed solidarity with the nation in their suffering and in their guilt. They accused themselves, not others.

The famous analysis by Karl Jaspers of four different types of guilt in Die Schuldfrage (1946) was often discussed in such South African discourse on confessing guilt. ${ }^{16}$ Jaspers distinguished between criminal guilt, political guilt, moral guilt and metaphysical guilt. In terms of this analysis, the Truth and Reconciliation Commission addressed primarily criminal guilt (perpetrators of gross violations of human rights). The South African discourse on confessing guilt in the 1980s grappled especially with the political and moral forms of guilt. Confessing guilt was a term used especially in three contexts, namely the Dutch Reformed Church, ${ }^{17}$ the National Initiative for Reconciliation ${ }^{18}$ and, more controversially, also within the South African Council of Churches (SACC). Here I will only focus on the role of the SACC.

\section{Discourse on Confessing Guilt in South Africa}

The SACC hosted a conference on confessing guilt in 1988 on the basis of the conviction that the time had already arrived to lay the foundations of a post-apartheid South Africa. Such discourse on confessing guilt was very controversial at the time. There was a sense that an emphasis of confessing guilt may weaken, endanger or even jeopardise the struggle

5 See De Gruchy, “Confessing guilt in South Africa today”, p. 34.

16 See especially John W de Gruchy, “Guilt, amnesty and national reconciliation: Karl Jaspers’ Die Schuldfrage and the South African debate”, Journal of Theology for Southern Africa 83 (June 1993), pp. 3-13.

17 There is an extensive literature on confessing guilt within this context. See especially David Bosch, Adrio König \& Willem Nicol (reds), Perspektief op die ope brief (Pretoria: Human \& Rousseau, 1982). See also the famous confession of guilt by Prof Willie Jonker in Louw Alberts \& Frank Chikane (eds.): The road to Rustenburg (Cape Town: Struik, 1991), p. 92.

18 See especially Klaus Nürnberger \& John Tooke (eds.): The cost of reconciliation: NIR Reader 1 (Cape Town: Methodist Publishing House, 1988). 
for freedom and democracy. What the oppressed needed most was not to seek reconciliation with repentant oppressors but liberation from oppression.

This has to be understood against the background of the Kairos Document (1985) which denounced talk about reconciliation as 'church theology'. It maintained that "it would be totally unChristian to plead for reconciliation and peace before the present injustices have been removed. Any such plea plays in the hands of the oppressor by trying to persuade those of us who are oppressed to accept our oppression and to become reconciled to the intolerable crimes that are committed against us." ${ }^{, 19}$ It was argued that good and evil cannot and should not be reconciled with one another. Black theologians such as Itumeleng Mosala and Tinyiko Maluleke went further by arguing that the primary need is not for reconciliation between black people and white people in South Africa: "Our alienation is not alienation from white people first and foremost. Our alienation is from our land, our cattle, our labour which is objectified in industrial machines and technological instrumenttation. Our reconciliation with white people will follow from our reconciliation with our fundamental means of livelihood.,20

Moreover, there was an honest fear that white Christians may hijack a public confession of guilt to obtain a cheap form of grace without justice. This would have put the oppressed - who would be called upon to forgive those who have confessed their guilt - in an unbearable position. Yet, there was also the recognition that the confession of guilt, repentance and conversion is fundamental to the nature of Christian life and indeed crucial to overcome the hatred and bitterness caused by decades of apartheid. The question was therefore what a confession of guilt could mean. Here a number of layers could be identified:

Firstly, the National Conference of the SACC adopted a resolution in 1985 which reads:

"The Conference believes that there is a need for confession of guilt by white Christians

for the unjust structures they have inflicted upon the black people of this land and requests the Division of Mission and Evangelism to devise ways and means of assisting individuals and congregations to come to this point., ${ }^{21}$ The emphasis is here on those Christians who actively supported apartheid, identified in overtly racial terms. The primary focus is the ways in which the policies of apartheid were actively and insistently propagated by the Dutch Reformed Church in the 1930s and the 1940s. However, this category also included those who ignored the evils associated with apartheid, who spiritualised the gospel and maintained a separation between church and society. Moreover, those who denounced apartheid, but who were rather slow in doing so, were also called to confess since this had allowed the status quo to prevail for too long.

Secondly, there was also a sense in which mainline churches supported apartheid, either actively, or through being themselves divided along racial lines, or through complicity and silence, or through not being courageous enough in resisting the system. The divisions since 1857 and 1881 between the various branches of the Dutch Reformed Church on the basis of race and ethnicity not only served as a kind of prototype for the apartheid policies that

19 See The Kairos Document: Challenge to the church, revised second edition (Johannesburg: Institute for Contextual theology, 1986), p. 10. Robert Schreiter therefore insists that "liberation is the necessary precondition for reconciliation”. See his Reconciliation: Mission and ministry in a changing social order (Maryknoll: Orbis Books, 1992), p. 25.

20 See Itumeleng Mosala, “The meaning of reconciliation”, Journal of Theology for Southern Africa 59 (July 1987), 19-25. See also Tinyiko Sam Maluleke, "The Truth and Reconciliation discourse: A black theological evaluation” in James Cochrane, John W de Gruchy \& Stephen Martin, Facing the truth: South African faith communities and the Truth and Reconciliation Commission (Cape Town: David Philip, 1999), p. 103.

21 See Bongani Finca et al, Confessing Guilt in South Africa, p. 13. 
followed later, but were also copied by several other denominations. The 1987 National Conference of the SACC adopted a second resolution in this regard, now calling for a conference on the question "whether Christian people can unite in a Confession of Guilt for the past". 22 This was evidently awkward for many church leaders in the SACC who dedicated themselves to the struggle against apartheid, but who belonged to churches that failed to do that. As church leaders they could not quite distance themselves from this form of guilt. There was indeed a need for repentance for the disunity of churches in South Africa. While Christians confessed to be of one body, they continued to move in separate worlds. This indicated a tension between one's political identity and one's ecclesial identity. It was much easier to identify with like-minded political activists than with unrepentant fellow Christians. For some the church was indeed their primary reference group, while others saw the SACC pragmatically as a helpful ally in the struggle against apartheid.

Thirdly, there were controversial intimations regarding the guilt of the oppressed themselves. Of course, such a confession of guilt by the victim may have been easily abused by the oppressor. The danger was that the guilt of the victims could be seen as somehow on par with the sins of the oppressors. Some nevertheless suggested that black Christians have to repent of their bitterness for what whites have done. Bongani Finca acknowledged at the time that there was a growing desire for revenge by a generation of blacks who have been so hurt and dehumanised that they have become possessed by such a desire. ${ }^{23}$ The victim's guilt may include various aspects: a failure of courage to fight against the system, responding to it with timidity and fear, looking for ways of escaping suffering through making compromises, acquiescing in oppression and accepting its dehumanising impact, failing to be instruments of peace amidst growing intolerance, hating the oppressor and wishing the downfall of the oppressor (not only the downfall of the system), and not giving the oppressor the opportunity to change. A person such as Desmond Tutu during this time never stopped emphasising that there would be no liberation for the oppressed without the liberation of the oppressor.

Fourthly, the fierce black on black violence raging in the South African townships at the time should also be taken into account. Such violence was symbolised by the infamous necklace method of executing informers. This should be understood against the background of resistance against various forms of collaborating with an evil system and therefore against any compromises within the ranks of the struggle against apartheid. Such animosity, suspicions and forms of violence naturally created immense trauma and a sense of guilt.

Finally, there were also those who called for a vicarious confession of guilt. This has to be understood as a response to the human inclination towards self-affirmation and selfreliance and therefore not to accept responsibility and not to confess guilt. It is common for those who are truly guilty to blame it on others, on orders from above, on adverse circumstances. Since many were unwilling to confess their own guilt for maintaining apartheid rule, it was suggested by some Christians that the church has a tremendous responsibility to confess not only its own guilt, but also the guilt of others, "to repent of it as if all the guilt is entirely the guilt of the church". ${ }^{24}$ This kind of confession would indeed imply that the church would take all the guilt upon itself vicariously. When the church becomes willing to confess, on behalf of the world, the possibility of forgiveness arises.

22 See Confessing guilt in South Africa, p. 13.

23 See Confessing guilt in South Africa, p. 23.

24 See Johan G Botha, "Struggling with the confession of guilt - Recent developments within the SACC” in Confessing guilt in South Africa, p. 19. See also his doctoral thesis entitled Skuldbelydenis en plaasbekleding, Teks en Konteks 5 (Bellville: Universiteit van Wes-Kaapland, 1989). 
This discourse on confessing guilt in South Africa culminated at the national conference of church leaders held in Rustenberg in November 1990. In the Rustenberg declaration there is a lengthy section on confession (of guilt). Here the church leaders confess that "we have in different ways practised, supported, permitted or refused to resist apartheid" (section 2.5). ${ }^{25}$ The document then continues to spell out these different ways, covering the full range mentioned above. In terms of the notion of being beneficiaries of apartheid these different ways included the following formulation: "we have been unwilling to suffer, loving our comfort more than God's justice and clinging to our privilege rather than binding ourselves to the poor and oppressed of our land.,26

\section{Accepting Responsibility in a Context of Climate Change}

Can the South African analogy help us to understand what would be at stake in the context of climate change? Let me offer a number of brief observations in this regard:

- Firstly, responsibility for climate change is remarkably measurable compared to complicity in the apartheid system. It is measured primarily in terms of carbon dioxide emissions. This should be measured not only in terms of what is directly consumed but also in terms of the energy embodied in the products we use and in the public services from which we benefit. While we have significant control over the former, it is far more difficult to assess the latter.

- Secondly, this carbon footprint cannot be reduced to one's own current greenhouse emissions. Such a carbon footprint has to be measured over a lifetime since it is the cumulative impact of greenhouse gases that is posing the problem. Europe and America between them are responsible for more than $90 \%$ of the emissions that are already in the atmosphere. For Westerners, the whole legacy of industrialisation since 1800 should therefore be factored in, if only because the forms of technology which we currently employ would not have been possible without two centuries of experimentation before us. The Kyoto protocol therefore rightly takes historical imbalances in greenhouse emissions into account.

- Thirdly, the history of trade and relationships between the West and the East, as well as the ways in which this has been shaped by Christianity, makes this extraordinarily complex. Countries in Europe and North America scarcely have the moral authority to require from Asian countries to reduce their per capita carbon emissions to levels that are significantly lower than their own. ${ }^{27}$

- Fourthly, the inequalities between powerful economic centres and those marginalised on the economic periphery have to be addressed (see the introduction above). The problem is that the consumer class is setting examples of a lifestyle that the lower middle class and also the poor wish to imitate. Through the advertising industry this lifestyle is

25 See Alberts \& Chikane, The road to Rustenburg, p. 277. See also the report by the Research Institute on Christianity in South Africa, commissioned by the Truth and Reconciliation Commission to advise the commission on its hearings dealing with submissions by faith communities. The report offers a thorough analysis of the various stances adopted by faith communities to apartheid. See "Faith Communities and apartheid: The RICSA report” in Cochrane, De Gruchy \& Martin, Facing the truth, p. 15-80.

26 See section 2.6 of the Rustenburg declaration in Alberts \& Chikane, The road to Rustenburg, p. 278.

27 As Sallie McFague observes, "While other countries such as China and India may equal or surpass the West in greenhouse emissions in the future, we Westerners have been the preachers of consumerism as the good life. We have not only produced the vast majority of emissions to date, but we export consumerism around the world as the heartbeat of every nation's prosperity." See her Life abundant: Rethinking theology and economy for a planet in peril (Minneapolis: Fortress Press, 2001), p. 92. 
deliberately portrayed as the norm to be followed. This stimulates the consumerism of the poor and the lower middle class.

- Fifthly, there is the tension between the current and future generations. Although the impact of climate change is already visible, it will be far more significant in 50 years time. In a probably unprecedented way, our toxic waste products, our use of nuclear energy and our use of fossil fuels will have a direct impact on our grandchildren who will experience the daunting reality of climate change and will have to deal with nuclear and other forms of waste and with nuclear power plants that have to be decommissioned.

On the basis of these observations there is a clear imperative for industrialised countries and those in the consumer class to accept the moral responsibility to radically curtail their emissions over the next few decades (mitigation) and to compensate the victims of climate change, to help them adapt to a changing climate and where necessary to migrate to less threatened terrains (adaptation). ${ }^{28}$ The question is what would be required to bring people to such a sense of responsibility in the first place. It is here that the Christian language of confessing guilt, forgiveness and reconciliation can play a crucial role. But what could these concepts possibly mean in a context of climate change?

\section{Confessing guilt in a Context of Climate Change?}

Christians like myself who have a relatively large carbon footprint, who are well informed about environmental matters and who recognise the dangers of climate change, have a serious problem. Like the beneficiaries of apartheid it may be possible, by God's grace alone, to accept and specify one's responsibility ${ }^{29}$ towards causing climate change, to recognise one's guilt and to show remorse. However, it is not self-evident how one could take the next step, namely to confess one's guilt. Here a number of questions require clarification:

Firstly, it is not self-evident that one could actually confess guilt, even if one recognises one's guilt before God, other human beings near and far and one's children. How does one confess guilt in such a context? In the case of apartheid one could declare that apartheid is evil, adopt alternative political views, seek to persuade others to do likewise and withdraw one's direct support for the forces that maintained the system. (Admittedly, that was difficult because a proportion of the income tax and VAT paid were used by the government of the time for military purposes.)

In the case of climate change this is more complex. Yes, one may criticise the forces that support neo-liberal capitalism and benefit from globalisation (including business corporations and their shareholders hoping for a good return on their investments). One may promote policies that would be more sustainable. One may also recycle waste, live frugally, save energy, use public transport and adopt an alternative, environmentally friendly lifestyle. But whenever I drive my (small) car to work (with others as far as possible),

28 See Northcott, A moral climate, p. 181.

29 It is indeed to crucial to specify one's responsibility in this regard as far as this is possible. Christian confession of guilt is an exercise in naming (see Jennings, The liturgy of liberation, p. 68-73). The problem is that a generalised sense of responsibility for causing climate change will also lead to vague measures in addressing carbon emissions. Moreover, from a pastoral perspective, it is inappropriate to burden individuals with guilt for a problem that they did not cause and cannot carry on their own. There is also the Protestant danger of an "arrogant assumption of guilt". Those who believe that they are responsible for everything also tend to think that they must really have control over everything. See Jürgen Moltmann, A broad place (Minneapolis: Fortress press, 2008), p. 279, with reference to German post-war discourse on anti-Semitism. 
whenever I switch on my computer or take a (brief) hot shower in my suburban home, whenever I check the latest interests received on my financial investments and whenever I fly to a conference (on climate change!) I contribute to the problem. In response, I can voluntarily contribute to a fund to pay compensation for my carbon emissions, but if I fail to reduce my direct and indirect emissions I remain guilty. How can one confess guilt with sincerity if one continues to contribute to the problem daily, if one's carbon footprint remains much larger than that of others?

This is the classic Christian problem of recognising that sin continues to plague the lives of those who are forgiven. But what should be done? Luther's profound counsel to 'sin bravely' in the knowledge of being forgiven by God already is in the context of climate change more dangerous than ever before. Bonhoeffer's advice to accept responsibility, if necessary to take guilt upon oneself courageously, rather than to refrain from acting for fear of being guilty, is not particularly helpful here either. Indeed, what is necessary is to refrain from emitting more and more greenhouse gases.

Secondly, there is the question as to who should confess guilt. The whole of humanity? Only the consumer class? Also the less affluent with consumerist inclinations? Is it meaningful to talk about collective or corporate guilt or only individual guilt? How are such collectives to be circumscribed? Would this also include the guilt of one's ancestors? Is it meaningful to talk about such a confession of guilt outside Christian communities? Should one in the case of climate change perhaps focus only on Christians in the consumer class?

Christians should certainly not be too quick to speak about the guilt of others. It has quite enough guilt of its own to confess. Moreover, the Christian language of guilt, remorse and confession that is appropriate within a worshipping community may not be appropriate in civil society. ${ }^{30}$ The logic of confession and forgiveness cannot merely be replicated outside the church where discourse on carbon credits and carbon trade may be more applicable. An ethics of responsibility, which would entail the task of finding ways of addressing the injustices and legacies of the past and of working for a just future, may perhaps be more appropriate here than theological categories such as guilt, confession, forgiveness and reconciliation. ${ }^{31}$ What may be needed is not immobilising feelings of guilt, but a commitment towards the future.

Thirdly, to whom should one confess guilt? To one's own household? To the poor? To one's grandchildren? To other forms of life? And what could forgiveness mean in this context? Forgiveness here cannot be offered in any direct way. How could Muslims in Bangladesh forgive me for my carbon footprint? How could they do that if they (or their children) may well become environmental refugees within the next few decades? How could my unborn grandchildren forgive me for something that they may well, but have not yet experienced? Would future generations forgive present industrialised consumers? Why, they would ask us, if you heard what the scientists were telling you, did you not change before it was too late?

Fourthly, following these questions, it is also important to consider the question how such guilt may be confessed. How do collectives communicate with one another? How are such collectives defined and how can stereotypes be avoided here? Through their representatives only? What kind of languages, gestures and symbolic actions may be used so that

30 Accordingly, Theodore Jennings suggests that the proper locus for discussion the confession and forgiveness of sins is the Christian liturgy. See his The Liturgy of liberation (Nashville: Abingdon Press, 1988).

31 See Dirk Smit, Essays in public theology (Stellenbosch: SUN Press, 2007), p. 2007 with reference to the notion of confessing guilt in the context of the Truth and Reconciliation Commission. 
the message would be understood by those on the other side? What is necessary in order to ensure that such confessions do not degenerate into acts of opportunism and self-defence ${ }^{32}$

The question is also what such a confession of guilt would possibly lead to? To forgiveness? But then by whom? To reconciliation? But what could such reconciliation mean? And what forms of restitution and compensation would be possible and appropriate in the face of imminent climate change? Is this term not best used in the context of interpersonal relationships and perhaps also well-defined social groups (families or neighbourhoods) and social institutions (competing schools, sports clubs or businesses)? Can it also be used to speak of reconciliation between population groups (as assumed in the context of the TRC)? And what about structural divisions between the affluent and the poor? What may be done when large sections of the population come into confrontation with each other due to structural violence (as in the case of apartheid)? Could it be at all meaningful to talk about reconciliation between this and previous or coming generations?

An alternative would be to see the purpose of such a confession of guilt merely as a form of public commitment to environmental justice. This seems to be the direction in which several biblical injunctions are pointing. Reconciliation is only possible on the basis of doing justice, by first addressing the issues that are so divisive (Matt 5:23-24). What is required is international and inter-generational justice, not rituals of sacrifice (Micah 6:6-8). Sacrifice is born from recognition that the deficit of debt owed to God cannot be paid back. ${ }^{33}$ Reconciliation between God and humanity is therefore only possible if the deficit is written off, if it is forgiven. Through rituals of sacrifice one offers part of the whole deficit in the hope that this would be seen as symbolic for the whole. It may be taken for granted all too easily that such an offering would indeed suffice for the whole. What is called for in the context of climate change is not premature forgiveness. Justice may sometimes follow on reconciliation but at times it may also be the condition for reconciliation. In secular terms: only if we do manage to stabilise greenhouse gases below $450 \mathrm{ppm}$ of $\mathrm{CO}_{2 \mathrm{e}}$ may we forgive ourselves the deficit, that is, our inability to restore greenhouse gases to preindustrial levels.

Amongst the available ecumenical confessions of guilt in a context of economic injustices and ecological degradation, the Accra statement of the World Alliance of Reformed Churches (2004) may be cited as one example.

\section{Asking for God's Mercy and Forgiveness?}

These questions may leave one with the impression that Christian views on reconciliation have little to offer in the face of climate change. That may well be what non-Christian dialogue partners would suggest. In international negotiations on climate change talk about quotas for carbon emissions, trading and taxes may be more appropriate. Here forgiveness certainly cannot imply condoning the ways in which some contribute to the problem at the expense of others.

32 See Geiko Müller-Fahrenholz, The art of forgiveness: Theological reflections on healing and reconciliation (Geneva: WCC, 1997), 60-61.

33 This deficit is typical of ordinary human relationships. For example, if I accidentally bumped into my neighbour's car, I can cover all his financial costs, but there is nothing that can undo the time lost and the frustration caused by the accident. There will always be a deficit, even if I offer my neighbour a nice gift as compensation. The deficit can only be forgiven by the offended party. Likewise, sacrifices are brought in recognition of this deficit and in the hope that this deficit will indeed be forgiven. 
Yet, the immense complexity of the problem may also help Christians to finally realise that this is a predicament way beyond their own power, that we are caught in the trap of a web of guilt, in what liberation theologians have called structural or systemic violence, that we cannot escape from the sins of the past, that our own good intentions remain deeply flawed and that the impact of our intentional actions may prove to be highly ambiguous. The Christian conviction is that guilt is not primarily located in what we have done, not in isolated deeds, but in our identity as a person, as a community, indeed as a whole civilization. We cannot separate ourselves from our actions and think that we may have done something wrong, but that we remain on the whole inherently good people, that the underlying principles of our societies, our democracies, our market economies are appropriate. This would lead to a superficial, moralistic and legalistic notion of guilt. The problem is not only what we do and have done, but who we collectively are. ${ }^{34}$ Moreover, as the Christian tradition has maintained, sin is not merely a description of our distorted relationships with others, but primarily of our alienation from God. As Gregory Jones observes, "The crisis of the human condition is not simply my individual guilt, but rather the evil, suffering and brokenness - the 'universal situation of disaster' - that undermines not only my communion with God but our communion with God and with one another.”35

In this context it may become appropriate for Christians, especially those of us with a large carbon footprint, to confess our indebtedness to Godself and not only to our victims. We may reach a point where we may also need God's forgiveness. Gregory Jones notes that, "the restoration of our communion with God requires something beyond my repentance, beyond my initiative or any human initiative, but not beyond God the Father's gracious will for communion with Creation." 36 This is the point where we need to realise the distinction between the church's ministry of reconciliation and what Christ has done outside us (extra nos) and on our behalf (pro nobis) and not only in us and through us (in nobis), once and for all (the ephapax of Rom 6:10). This is where we may recognise that we need not be burdened with doing God's work, that what holds the ecclesial community together is not common moral activity, that there is a fundamental asymmetry between divine and human action, an unbridgeable gulf between the work of Christ through which God reconciled the world to Godself (2 Cor 5:19) and our ministry of reconciliation. ${ }^{37}$

Especially in the reformed tradition, it has been recognised that the confession of guilt is not something that comes naturally. While the presence of evil may be empirically evident, it is not self-evident that I have to accept responsibility for such evil. It is far easier and more natural to accuse others and to sidestep responsibility. My small children are sometimes willing to confess their own complicity but are typically very quick to add "but the other one also did something wrong”,

Here one may refer to the deeper insight that the knowledge of sin only becomes possible through God's grace, through God's self-disclosure, through the recognition that God's

34 See Dirk Smit, “Confession-guilt-truth-and-forgiveness in the Christian tradition: in Botman \& Petersen (eds.), To remember and to heal (Cape Town: Human \& Rousseau, 1996), p. 106.

35 See Embodying forgiveness, p. 117. See also his discussion (p. 59-64) on the structural differences between sinning against one another (“sins”) and sinning against God (“Sin”).

36 See Embodying forgiveness, p. 118.

37 See the perceptive essay by John Webster, “The ethics of reconciliation” in Colin Gunton (ed.): The theology of reconciliation (London: T \& T Clark, 2003). He comments: "The church, therefore, lives in that sphere of reality in which it is proper to acknowledge and testify to reconciliation because we have been reconciled; in which it is fitting to make peace because peace was already made; in which it is truthful to speak to and welcome strangers because we ourselves have been spoken to and welcomed by God, and so have become no longer strangers but fellow-citizens” (p. 120). 
mercy and affirmation is more fundamental than our guilt. Accordingly, sin that is known and confessed is known to be forgiven already. ${ }^{38}$ We do not see the problem until we are grasped by the solution (Karl Barth). Otherwise guilt would become unbearable. This knowledge of being forgiven already is what makes the confession of guilt and of sin possible, quite distinct from other acts of mediation, ${ }^{39}$ and joyous. As Bonhoeffer recognised, open confession is good for the soul, it liberates those in all too pious Christian communities from attempts to hide their sins from one another. Confession allows people to be who they are: forgiven sinners before God. ${ }^{40}$

The question is whether this is also true in the context of climate change. Can we sincerely claim to be forgiven by God? Or is this perhaps the deeper reason why it is so difficult to confess guilt in this case - because we sense that we are not (yet) forgiven, not by ourselves, nor by others and perhaps not even by God? How can we continue with our consumerist lifestyles if we know what the long-term impact of that will be? Clearly, we cannot assume that forgiveness by God will follow such confession more or less automatically.

My intention here is not to resolve this unbearable question. Various theological traditions may respond to this question in different ways (ranging from a sense of gratitude to human cooperation with God's will), each emphasising the need for a commitment to climate justice. I am also not merely calling for such a confession of guilt - since that cannot be prescribed if indeed this only becomes possible through experiences of God's forgiveness. Instead, I wish to highlight what happens when language about guilt, confession, forgiveness and reconciliation is eschewed.

For many the solution would seem to be that we have to save ourselves and our world through our collective efforts. Thus we manage to forgive ourselves for flying around the world to attend ecumenical conferences, especially if they are on climate change. Others forgive themselves on the basis of their creative efforts at home and at work to find carbonneutral sources of energy (and then they can accuse managing directors of multi-national companies for not doing likewise!). Some buy carbon credits to offset their high footprint, following the pattern of medieval indulgences, in order to purchase forgiveness so that they can forgive themselves. People (like myself) who are not that creative or practical console ourselves by working equally hard to conscientise others, by writing books on climate

38 Confession of guilt and repentance therefore cannot be demanded from or imposed on others (for whom it would cost little); it is a gift from the Holy Spirit. See David Bosch, "Processes of reconciliation and demands of obedience - Twelve theses”, in Nürnberger \& Tooke (eds.): The cost of reconciliation, p. 108.

39 See Webster, “The ethics of reconciliation” (p. 118): “'Reconciliation' is not a reality which is generally well known and understood, something to which the Church also makes its particular contribution and lends its authority but the content of which is not strictly derivable from the content of the Church's proclamation of salvation. The Church is not simply as it were a volunteer, willing to spend itself in a task for which others are also suited, but in which they decline to involve themselves. The Church engages in actions which are given to it to do by its constitution as that gathering of humanity which confesses that in Christ God has reconciled the world to himself.”

40 Bonhoeffer's description of the self-deception of the pious community remains classic: "For the pious community permits no one to be a sinner. Hence all have to conceal their sins from themselves and from the community. We are not allowed to be sinners. Many Christians would be unimaginable horrified is a real sinner were suddenly to turn up among the pious. So we remain alone with our sin, tapped in lies and hypocrisy, for we are in fact sinners.” He then emphasises the breakthrough to community through the practice of confession of sins: "Sin that has been spoken and confessed has lost all of its power. It has been revealed and judged as sin. It can no longer tear apart the community. ... The sinner has been relieved of sin's burden. Now the sinner stands in the community of sinners who live by the grace of God in the cross of Jesus Christ.” See his Life together (Minneapolis: Fortress Press, 1996), p. 108-110. See also Jennings, The liturgy of liberation, p. $65 \mathrm{f}$. 
change! Yet others opt for self-isolation by adopting a monastic lifestyle, with a small carbon footprint, nicely secluded from the world of international discourse on climate change - in the hope that this may set an example for others and that God would forgive them on that basis.

Thus, living without God's forgiveness, we are forced to frantically and anxiously work for change in order to save ourselves. Some may be satisfied with such commendable dedication, but this does not yet resolve the underlying inequalities and tensions. A sense of responsibility and a commitment to justice are crucial, but Christians may hope and pray for more - for reconciliation through Jesus Christ and for God's shalom.

\section{Praying for Deliverance from Evil?}

While Christians with a large carbon footprint may find it difficult to confess guilt, Christians with a small carbon footprint, especially in Africa, may opt for a different understanding of redemption. ${ }^{41}$ If those responsible for climate change do not confess their guilt and do not reduce their carbon footprint, the current and the future victims of climate change cannot really forgive the perpetrators either since reconciliation would not be possible on that basis. Instead, they may hope for delivery from the looming impact of climate change. They may also work for sustainability with whatever little access to power they have. They may warn against the temptations of consumerism and the prosperity gospel in their own midst. They may promote alternative sources of energy in impoverished rural communities. And they may offer a prophetic critique if and when they do come to the dialogue table. There they may denounce unsustainable practices, economic injustices and warn about the consequences of an inability to act now.

However, there may well come a point where they realise that the looming crisis will not be averted. There may be an increasing awareness of the challenge of climate change and there may be many who explore viable alternatives. But what if, in four decades' time, we collectively fail to stabilise carbon emissions below $450 \mathrm{ppm}$ of $\mathrm{CO}_{2 \mathrm{e}}$ ? Then the victims of climate change may well have to put their hope and trust in God alone. They may then pray for delivery from evil, because apparently only God would be able to rescue us from such a looming disaster. Only God would be able to overcome the forms of evil that have so infested human societies. But how would this come about without human instruments in God's hands?

The prayer for deliverance from evil should also not be undertaken lightly. Evil cannot always be isolated, eradicated and terminated. History is littered with examples indicating that the more radically this is done, the more dramatically evil may manifest itself in other forms, including in what is supposed to be good and in the apparatus set up to repress evil. It is therefore wise to reckon with a much wider compass of latent evil. ${ }^{42}$ Evil is more evasive, more widespread and less fathomable than one may wish to consider.

Moreover, the problem is not merely that the forces of the Light are battling with the forces of Darkness. Evil also lurks in the heart of the victim. Here the South African

41 I am drawing here on the classic typology of three types of atonement introduced by Gustav Aulén, adapting and translating this typology within a pneumatological context. Salvation has been understood in the Christian tradition in especially three ways, namely as victory over the forces of evil, destruction and death/liberation from oppression, as forgiveness and reconciliation amidst alienation and as finding an inspiring example to follow. See also my essay on "Healing in soteriological perspective”, Religion \& Theology: A Journal of Contemporary Religious Discourse 13:1 (2006), 3-22.

42 See Wolfhart Pannenberg, Systematic Theology: Volume 2 (Grand Rapids: WB Eerdmans, 1994), 237. 
analogy may again be helpful. During the dark years of apartheid it was possible to draw the lines sharply between good and evil - although that was blurred by the role of people such as Beyers Naude on the one side and collaborators and informers on the other. A decade or so into the democratic dispensation this is no longer possible. Most South Africans now recognise that it is all too facile to blame just about everything on apartheid. Within the current South African context there seems to be recognition that the lines between those who are sinners and those who are sinned against cannot always be drawn sharply. This is typically true in the case of marriage trouble, family feuds, community conflicts and even in the case of labour disputes. All too often we are both victimised and perpetrators at the same time. This is especially evident from the impact of crime and gangsterism but also from the HIV/AIDS pandemic in South Africa. It is this alwaysalready brokenness in the human condition that is described in the Christian tradition with the category of $\sin$. $^{43}$

This is even more pertinent given the impact of consumerism (as an ideology) on both the affluent and the poor. Ironically, some affluent people may come to recognise that money is not everything. By contrast, Richard Foster may be putting his finger where it hurts in saying about the love for money that: "Those who have it the least, love it the most!” In such a context of rampant consumerism it may be liberating to recognise finally (but not prematurely) that we are all sinners, whether with a large or a small carbon footprint, that confession is more appropriate than mutual accusations and that we are all in need of God's liberating word of forgiveness. This suggests the need for ecumenical reflection on confessing guilt in the context of climate change.

\section{Conclusion: On Solidarity with the Victims of Climate Change}

Is there then no sense of hope and expectation in a context of climate change? Of course, the primary hope would be that a disaster can be averted, that our children's children will forgive this generation its blind commitment to ever greater consumption, ${ }^{44}$ that we will collectively be able to adopt more sustainable lifestyles, that we will all experience that as beneficial for our health and happiness, that the inequalities of the age of consumerism will be addressed. Here we may require another notion of redemption: we need inspirational examples to follow, appropriate policies and guidelines for sustainable living. There is still time to change our ways. An apocalyptic sense of divine judgement is not yet appropriate and will play in the hands of those prophets of doom who cannot and will not contribute to an alternative, whose message cannot energise action.

Yet, as the WCC warns in its study document Solidarity with the victims of climate change (2002), the response from the international community has not been commensurate with the enormity of the challenge. Change is unlikely to come through persuasion alone. Change may come as a result of upheavals, but that will entail immense suffering. In such a context the church is called to stand in solidarity with the victims of climate change. At an international level, structures will have to be put in place to respond to more frequent requests for emergency help and to rising tides of environmental refugees. This will require budget reserves and appropriate contingency plans to prevent disasters from occurring with the same devastating effects. It will also require strategies of adaptation to changed climatic conditions.

43 See Gregory Jones, Embodying forgiveness, p. 62.

44 John B Cobb \& Herman Daly, For the common good: Redirecting the economy toward community, the environment, and a sustainable future (Boston: Beacon, 1994), p. 400. 
However, there is no guarantee that such acts of resistance and solidarity will be crowned with success. The utopian hopes of so many revolutionaries of the past have lost much of their credibility. As the WCC notes, the struggle is now against the further degradation of the planet's ecosystems. Moreover, there is a distinct possibility that, under difficult circumstances, "love may grow cold" (Mt 24:12). In such a context the church needs to abide by its faith in God alone, in its vibrant hope despite visible success and in its love for the other. ${ }^{45}$

45 See Solidarity with victims of climate change: Reflections on the World Council of Churches' response to climate change (Geneva: WCC, 2002), p. 25-26. 